\title{
Antimicrobial activity of essential oils on pathogenic fungi
}

Daniele Aparecida do Couto ${ }^{1}$

Felipe da Silva Dias ${ }^{2}$

Mírian Lobo Sáber ${ }^{3}$

\section{Abstract}

Since the induction of chemical defensives in agriculture, human beings have suffered from our own actions, caused by the indiscriminate and abusive use of those substances; therefore, researches have been motivated to look for alternative ways, aiming to use plant inputs to control pathogenic agents in agriculture. As the essential oils from the species Eucalyptus globulus (eucalyptus), Callistemon viminalis (weeping bottlebrush), Cymbopogon winterianus (citronella grass) and Tetradenia riparia (misty plume bush) have proved effectiveness and an immense applicability, this research studied the use of those essential oils, aiming the effectiveness against plant pathogens. The plants were collected from Universidade do Vale do Sapucaí, Pouso Alegre (MG). The fungi's samples belong to the mycology collection from the institution and the tests were based on the mycelial development comparison of the control fungi on the dishes with essential oils. Notice that the inhibition caused by the oils over fungi's mycelial developing and the analysis of the data have been made through Turkey's statistic. From the data analyzed, it was possible to realize that the citronella's grass essential oil was efficient to control the mycelial development of fungi analyzed, followed by, in order of efficiency, the eucalyptus oil, the weeping bottlebrush oil and the misty plume bush oil.

Keywords: Citronella grass. Essential oil. Fungal plant pathogens.

\section{Introduction}

In 2008 Brazil assumed the first place at the defensive world market (AGÊNCIA NACIONAL DE VIGILÂNCIA SANITÁRIA - ANVISA, 2015). Since the induction of chemical defensives in agriculture, population suffers direct and indirect actions by abusive and indiscriminate use of these synthetic substances due to the fact that many of those have systemic elements and cumulative effects in organisms and go through all the food chains, contaminating soil and water sources (FERRARI, 1985; FLORES et al., 2004). Therefore, researches are induced to search for alternative ways such as plants inputs to control pathogens agents in agriculture.

The main pathogens in agriculture are fungi, responsible for $70 \%$ of the illness that compromise the productivity of most crops (POZZA, et al., 1999). The fungus success is caused by their reproduction, which is usually based formation of spores, and can be transported by water, wind and plants, being resistant to temperature oscillation and capable of staying inert in the soil for many years (KIMATI et al., 1997).

1 Universidade do Vale do Sapucaí, discente. daniiicouto@gmail.com.

2 Universidade do Vale do Sapucaí, discente. felipeuk@hotmail.com.

3 Universidade do Vale do Sapucaí, professora-doutora. mirianlsaber@gmail.com. Avenida Prefeito Tuany Toledo, 470, Pouso Alegre (MG), Brasil, CEP: 37550-000. 
As the demands for food to fulfill the necessity of a rising population and the attempt to reduce the impact on the environment intensify, new technics have been discussed and developed to re-establish the food quality we produce. Innovating studies, which use inputs from microorganisms (SILVA; COELHO, 2006) and plant essential oils (MEDICE et. al., 2007), have been standing out in science as possible substitutes for the defensives that are harmful to the environment.

Plant extracts and essential oil utilization have been known for a long time, since these compounds have medicinal and aromatic properties (NÓBREGA et al., 2003). The essential oils are found in different parts of a plant and they can be extracted from leaves, flowers, seeds, twigs or roots (KOKETZU; GONZALES, 1991). Studies showing essential oil activities over fungitoxic action (SILVA; BASTOS, 2007), antibacterial activities (PEREIRA et al., 2004), antioxidant (MORAIS et al., 2006), insecticide (MARANGONI et al., 2013) and herbicide (BARBOSA et al., 2008) prove plant essential oils efficiency.

Due to the evidences collected from tests with essential oil, the challenges to turn these technologies viable are many; however, it is necessary to intensify research and to turn the technology cheap and profitable. Since the essential oils from the species Eucalyptus globulus, Callistemon viminalis, Cymbopogon winterianus and Tetradenia riparia have proved effective against antimicrobial activity (PEREIRA, 2009; PIATTI et al., 2011), the present research aimed to study their application to control phytopathogens with tests on fungi for future use in agriculture.

\section{Material and methods}

The present study was developed at the Microbiology Lab at the Universidade do Vale do Sapucaí, located in Pouso Alegre city, Minas Gerais, Brazil, from February to November of 2015. The plants utilized in the present study were the eucalyptus (Eucalyptus g/obulus), the weeping bottlebrush (Callistemon viminalis), the misty plume bush (Tetradenia riparia) and the citronella grass (Cymbopogon winterianus). The species studied are found on the institution campus.

\section{Extraction of the essential oils}

The process used to obtain the essential oils from the studied plants was by hydrodistillation in a Clevenger-type apparatus, method developed by Koketsu and Gonçalves (1991). The part from the plants used for extractions of essential oils were the leaves; at first, they were left to dry at room temperature for two days aiming to eliminate the excess of water; after that, 1 kilogram of each plant was submitted to hydrodistillation for one hour. Then, the essential oils were collected with a Micropipette, stored in amber flasks and kept at $5^{\circ} \mathrm{C}$ temperature to be used afterward.

\section{Preparation of culture medium}

To reactivate the fungus and to do the antibiosis test in vitro, Potato Dextrose Agar (PDA) medium, made with $200 \mathrm{~g}$ of potato extract, $20 \mathrm{~g}$ of Dextrose and $15 \mathrm{~g}$ of Agar for each $1000 \mathrm{ml}$ of water, was employed. Powdered PDA was diluted in distilled water at the concentration demanded at the product's labels; afterwards, it was autoclaved for 20 minutes at $121^{\circ} \mathrm{C} / 1 \mathrm{Atm}$ temperature. Following, the medium was cooled at temperature around $45{ }^{\circ} \mathrm{C}$, in a sterile environment, in the Laminar Flow Cabinet, and bedded in $9 \mathrm{~cm}$ Petri dishes. 


\section{Antimicrobial test "in vitro"}

The studied plant essential oils were diluted in dimethyl sulfoxide (DMSO) to obtain different concentrations of oils: 0,5\%, $1 \%, 5 \%, 10 \%, 15 \%, 25 \%, 35 \%, 45 \%, 50 \%$ and $100 \%$. Before it, the DMSO was tested to check if it could contribute to the inhibition of the fungus; as the results were negative, the experiment was carried out.

The fungi used in the experiment were previously cultivated at $28{ }^{\circ} \mathrm{C}$ for seven (7) days. After the growth, circular fungus fragments of $1 \mathrm{~cm}$ of diameter were transferred to the center of the Petri dish, with the PDA medium. Subsequently, four circular fragments of sterilized paper filters were added in accordance to Bauer et al. (1966) disk diffusion method. In every paper disk, $10 \mu \mathrm{L}$ of each essential oil in concentrations from $0,5 \%$ to $100 \%$ were added, each treatment was placed at 3 $\mathrm{cm}$ distance from the fungus. The negative controls were made from Petri dishes with the fungus and sterilized paper filter. All the tests were carried out three times and the dishes were incubated at 28 ${ }^{\circ} \mathrm{C}$ temperature.

The determination for the mycelial growth of the plant pathogen fungus from the oil was made in six sets, through metrical evaluation of the mycelial growth size, with the help of a pachymeter; four oils to each fungus were compared by Tukey test at $5 \%$, using Assistat software (Statistical Assistance), version 7.7 beta.

\section{Results and discussion}

\section{Essential oils activity towards Pestalotiopsis sp. fungus}

The experiment carried out with the four essential oils on Pestalotiopsis sp. fungus showed this microorganism has the mycelial growth reduced when exposed to higher concentration of oils, as it can be observed in figure 1.

Figure 1. Comparative of Mycelial growth for Pestalotiopsis $s p$. towards the essential oil of Eucalyptus g/obulus, Cymbopogon winterianus, Tetradenia riparia and Callistemon viminalis with different concentration when compared with the fungus control, average with different letters are significantly different, according to Tukey test $(P>0,05)$

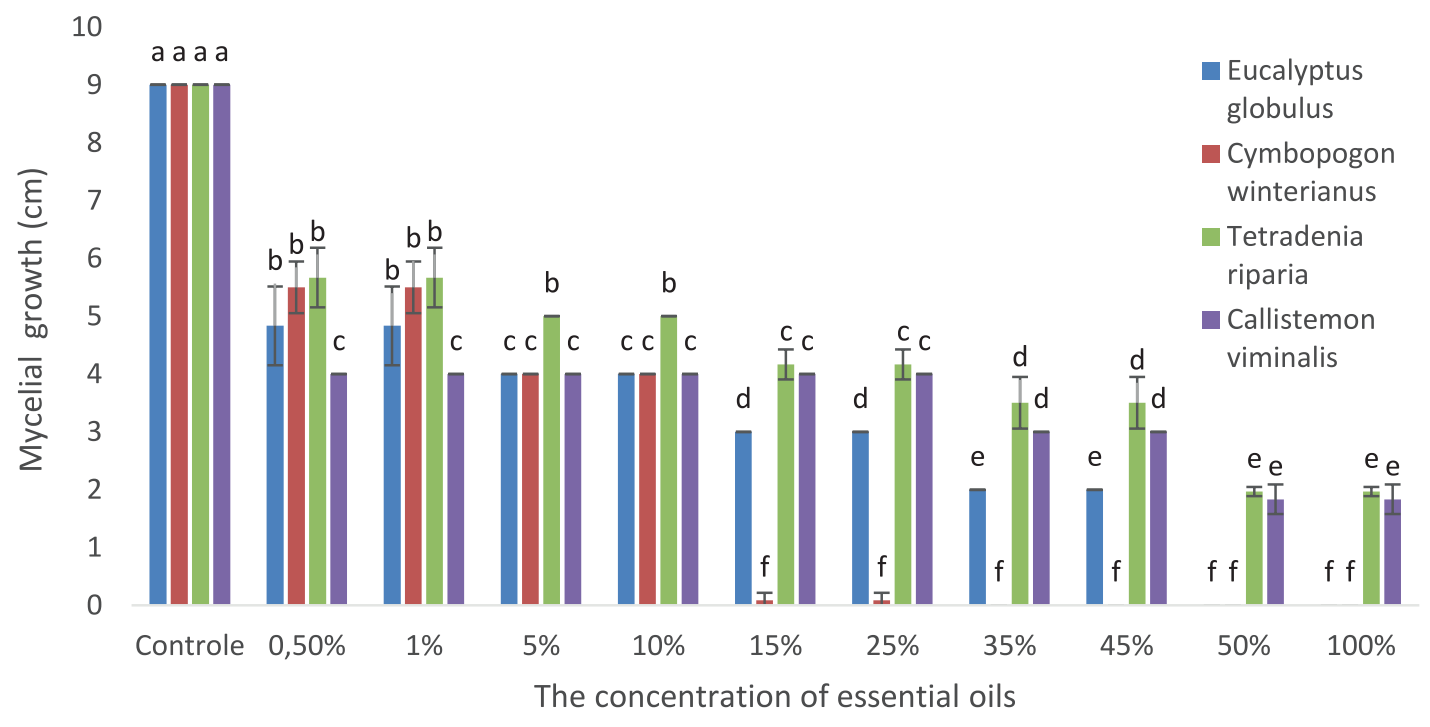

Source: Elaborated by the authors (2015) 
The essential oil of Cymbopogon winterianus showed greater inhibition for Pestalotiopsis sp. fungus, demonstrating a complete mycelial inhibition at $35 \%$ concentration, followed by the Eucalyptus globulus oil, which had a complete mycelial inhibition at $50 \%$ concentration.

Many authors have also proved the fungicide action for the essential oil from Cymbopogon winterianus against the fungus Trichophyton rubrum, Trichophyton mentagrophytes (PEREIRA, 2009) and towards the fungus Alternaria sp., Cladosporium sp., Rhizopus spp. (ARAUJO NETO; ARAúJO, 2012) and Fusarium solani (CRUZ et al., 2015), which emphasizes that oil as a potential fungicide.

The E. globulus oil has also demonstrated a great inhibition for the Penicillium pathogenic fungus in the Vegetative state as well as in the reproductive stage and spore germinations with the concentration equal or higher than 0,25\%. According to Piatti et al. (2011), the eucalypt oil has demonstrated to be more efficient than the fungicide Azoxystrobin.

The chemical compounds from the eucalypt essential oil are many and very complex, for example, 1,8-cineol, citral, citronellal, geranylol ethyl, among many others that have antifungal action (NAGPAL et al., 2010). The results support the data for the antimicrobial potentiality of Eucalyptus oil, especially on fungus, microorganisms that can be better controlled by natural products.

The essential oil of eucalypt, according to Piatti et al. (2011), does not present toxic activity towards human being nor the environment, what makes that oil viable to be applied on food cultivation, avoiding pathogenic microorganism activity and use of chemical defensives harmful to the environment.

\section{Essential oils activity towards Rhizopus spp. fungus}

The study with Rhizopus spp. fungus showed this microorganism has great resistance towards the essential oils, even when used at high concentration, as it can be observed in Figure 2.

Figure 2. Comparative of mycelial growth for Rhizopus spp. towards the essential oil of Eucalyptus globulus, Cymbopogon winterianus, Tetradenia riparia and Callistemon viminalis with different concentration when compared with the fungus control, average with different letters are significantly different, according to Tukey test $(P>0,05)$

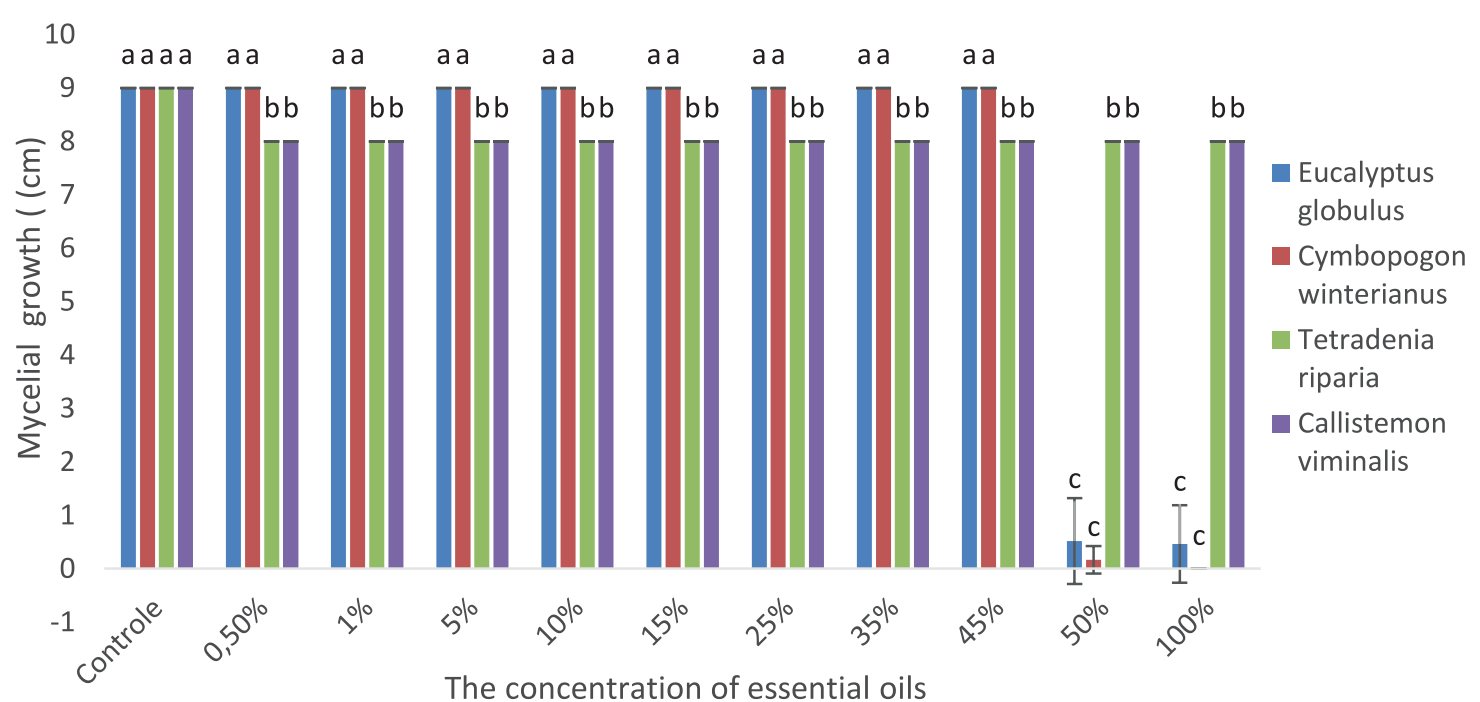

Source: Elaborated by the authors (2015)

All the concentrations of Tetradenia riparia and Callistemon viminalis essential oils have been incapable of reducing the mycelial growth of Rhizopus spp. On the other hand, the concentration of 
50 and $100 \%$ for Cymbopogon winterianus e Eucalyptus globulus oils have had a meaningful growth reduction.

According to Andrade et al. (2012), citronellal and linalol substances contribute a lot to the antifungal activities from the Cymbopogon winterianus (citronella). Different specimens have different concentrations of oil, but it was found that an average of $47,12 \%$ of citronella oil correspond to citronellal and linalool.

The essential oil from many plants have different chemical compounds according to the weather along the year, what affects the amount of compound available in the plants. Studies appoint results are not different for T. Riparia, since this plant has more chemical compounds during seasons with a higher frequency of precipitation, alternating its antimicrobial potential (GAZIM et al., 2010). That could explain the inefficient fungicide effects on Rhizopus spp.

\section{Essential oils activity towards Monilinia sp. fungus}

Monilinia sp. fungus showed susceptibility towards high concentrations of the essential oils tested, as it can be observed in Figure 3.

Figure 3. Comparative of mycelial growth for Monilinia sp. towards the essential oil of Eucalyptus globulus, Cymbopogon winterianus, Tetradenia riparia and Callistemon viminalis with different concentration when compared with the fungus control, average with different letters are significantly different, according to Tukey test $(P>0,05)$

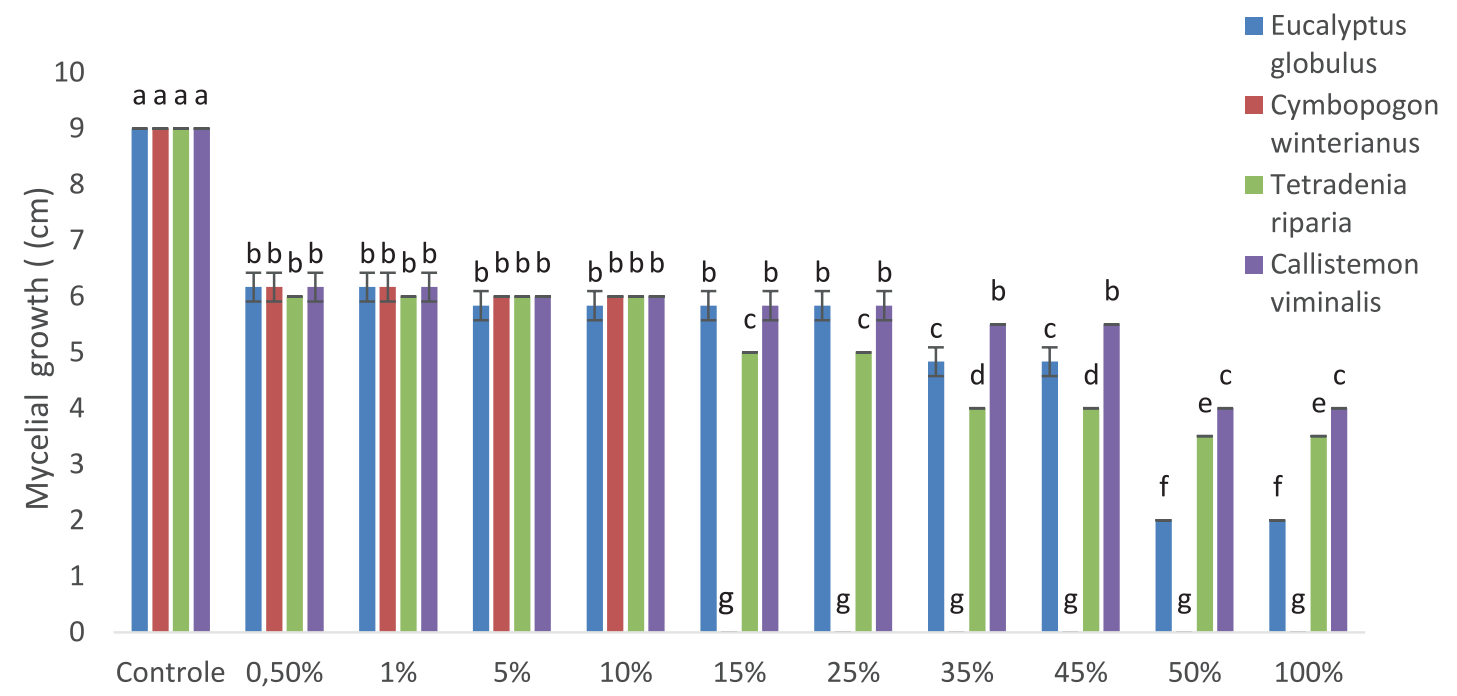

The concentration of essential oils

Source: Elaborated by the authors (2015)

The essential oils from Callistemon vimilanis, Tetradenia riparia and Eucalyptus globulus have demonstrated greater fungistatic activity at 50 and $100 \%$ concentrations.

According to Pieters and Vlietinck (2005), T. riparia has different compounds, including the diterpenes. During tests with this plant, Coopoosamy e Naidoo (2011) observed its efficiency to combat many human pathogens, such as the gram-positive bacteria, gram-negative bacteria and also tests with fungus (Aspergillus flavus, Aspergillus glaucus, Candida albicans and Candida tropicalis).

Plants from Callistemon genus are frequently used in traditional treatments because they have unique sources of many chemicals compounds with therapeutic activity. However, only a few studies about the biological activities and possible medicine uses of phytochemicals from $C$. viminalis have been conducted until today (GOHAR et al., 2013). 
According to Oyedeji et al. (2009), leaves from C. viminalis have 20 chemical compounds, among them: 1,8cineol (83,2 \%), apineno (6,4\%) aterpineol (4,9\%). 1,8cineol (eucalyptol) has proven to have anti-inflammatory action (BASTOS, et al., 2010).

The essential oil from Cymbopogon wintereanus has shown an efficient fungicide action, starting at $15 \%$ concentration. In the study conducted by Souza et al. (2006), the C. winterianus also presented itself as an efficient fungicide at high doses to control the Monilinia fructicola and a great mycelial inhibition similar to Triazole fungicide and superior to Azoxystrobin and the Eucalyptus oil.

\section{Conclusion}

From the information presented in this study, it has been concluded that the essential oil from Cymbopogon wintereanus at 50 and $100 \%$ concentration have had the most efficient fungistatic and fungicide activity on all the fungi tested. The essential oil of Eucalyptus g/obulus, Tetradenia riparia and Callistemon viminalis have shown only fungistatic activity on the fungi.

\section{Acknowledgment}

To professor Rogério Lobo Sáber, to Laboratory technicians Renan Neves and Eliakim Lopes and to José Donizeti Reis.

\section{Referências}

AGÊNCIA NACIONAL DE VIGILÂNCIA SANITÁRIA (ANVISA). Seminário Mercado de Agrotóxico e Regulação. 2012. Brasília: ANVISA. Disponível em: <http://portal.anvisa.gov.br/wps/content/ anvisa + portal/anvisa/sala + de+imprensa/ menu+noticias + anos/2012 + noticias/seminario+volta $+\mathrm{a}+$ discutir + mercado + de + agrotoxicos $+e m+2012>$. Acesso em: 10 nov. 2015.

ANdRAdE, M. A.; CARdoso, M. G.;. BAtista, L. R.; MALlet, A. C. T.; MACHAdO, S. M. F. Óleos essenciais de Cymbopogon nardus, Cinnamomum zeylanicum e Zingiber officinale: composição, atividades antioxidante e antibacteriana. Revista Ciência Agronômica, v. 43, n. 2, p. 399-408, 2012. Disponível em: <http://www.scielo.br/scielo.php?script=sci_arttext\&pi$d=$ S1806-66902012000200025>. Acesso em: 05 out. 2015.

ARAUjO NETO, A. C.; ARAÚJO, P. C. Atividade antifúngica do óleo essencial de citronela em sementes de erva-doce (Foeniculum vulgare mill.). Revista Verde de Agroecologia e Desenvolvimento Sustentável, v. 7, n. 1, p. 189-195, 2012. Disponível em: < http://www.gvaa.com.br/revista/ index.php/RVADS/article/view/1099/1114>. Acesso em: 18 out. 2015.

BARBOSA, C. S.; MAIA, F.; SANTOS, D. Q.; TERRONES, M. G. H. Potencial herbicida do extrato diclorometanólico de folha da lixeira (Curatella Americana L.). Seminário de iniciação científica, 12, p. 110, 2008. Disponível em: <https://ss/4799.websiteseguro.com/swge5/seg/cd2008/PDF/IC20080070.pdf > . Acesso em: 25 set. 2015.

BAUER, A. W.; KIRBY, W. M.; SHERRIS, J. C.; TURCK, M. Antibiotic susceptibility testing by a standardized single disk method. American journal of clinical pathology, v. 45, n. 4, p. 493, 1966. 
COOPOOSAMY, R. M.; NAIDOO, K. K. Assessing the potential of Tetradenia riparia in treatment of common skin conditions in rural communities of South Africa. African Journal of Microbiology Research, v. 5, n. 19, p. 2942-2945, 2011. Disponível em: <https://www.researchgate.net/publication/267303217_Assessing_the_potential_of_Tetradenia_riparia_in_treatment_of_common_skin_ conditions_in_rural_communities_of_South_Africa>. Acesso em: 18 set. 2015.

CRUZ, T. P. da; ALVES, F. R.; MENDONÇA, R. F.; COSTA, A. V.; JESUS JUNIOR, W. C. de; PINHEIRO, P. F.; MARINS, A. K. Fungicide activity of essential oil Cymbopogon winterianus jowit (Citronella) against Fusarium solani. Bioscience Journal, v. 31, n. 1, p. 1-8, 2015. Disponível em: $<$ http://www.seer.ufu.br/index.php/biosciencejournal/article/view/22346/15841>. Acesso em: 22 set. 2015.

DEQUECH, S. T. B.; SAUSEN, C. D.; LIMA, C. G.; EGEWARTH, R. Efeito de extratos de plantas com atividade inseticida no controle de Microtheca ochroloma Stal (Col.: Chrysomelidae), em laboratório. Biotemas, v. 21, n. 1, p. 4146, 2008. Disponível em: <https://periodicos.ufsc.br/index.php/ biotemas/article/view/2175-7925.2008v21n1p41/18967>. Acesso em: 22 set. 2015.

ERNAWITA; SULAIMAN, S. F. Composition and antimicrobial activity of crude extracts and essential oil of Callistemon viminalis leaves. Journal Biologi Edukasi, v. 1, n. 2, p. 4750, 2013. Disponível em: <http://jurnal.unsyiah.ac.id/JBE/article/view/414/584>. Acesso em: 25 out. 2015.

FERRARI, A. Agrotóxicos a praga da dominação: o custo ambiental e social de uma agricultura dependente. 2. ed. Porto Alegre: Mercado Aberto, 1985, p. 40-50.

FLORES, A. V.; RIBEIRO, J. N.; NEVES, A. A.; QUEIROZ, E. L. R. de. Organoclorados: um problema de saúde pública. Ambiente \& Sociedade, v. 7, n. 2, p. 111124, 2004. Disponível em: <http:// www.scielo.br/pdf/asoc/v7n2/24690.pdf>. Acesso em: 25 out. 2015.

GAZIM, Z. C.; AMORIM, A. C. L.; HOVELL, A. M. C.; REZENDE, C. M.; NASCIMENTO, I. A.; FERREIRA, G. A.; CORTEZ, D. A. G. Seasonal variation, chemical composition, and analgesic and antimicrobial activities of the essential oil from leaves of Tetradenia riparia (Hochst.) Codd in Southern Brazil. Molecules, v. 15, n. 8, p. 5509-5524, 2010. Disponível em: <www.mdpi.com/14203049/15/8/5509/pdf>. Acesso em: 22 set. 2015.

GOHAR, A. A.; MAATOOQ, G. T.; GADARA, S. R.; ABOELMAATY, S. W. The profile and antimicrobial activity of the essential oil from Callistemon viminalis (Sol. Ex Gaertner) G. Don Ex Loudon leaves. Journal of Biotechnology and Pharmaceutical Research. 3. ed., v. 5, n. 1, p. 711, 2013. Disponível em: < http://www.e3journals.org/cms/articles/1390478140_Gohar\%20et\%20al.pdf>. Acesso em: 10 ago. 2015.

KIMATI, H.; AMORIM, L.; BERGAMIM FILHO, A.; CAMARGO, L. E. A.; REZENDE, L. E. A. Manual de fitopatologia: doença das plantas cultivadas. 2. ed. São Paulo: Agronômica Ceres Ltda, 1997. v. 2, p. 621-627, 1997.

KOKETSU, M.; GONÇALVES, S. L. Óleos essenciais e sua extração por arraste a vapor. Rio de Janeiro: EMBRAPA, 1991 (EMBRAPACTAA. Documentos 8). 
MARANGONI, C.; MOURA, N. F.; GARCIA, F. R. M. Utilização de óleos essenciais e extratos de plantas no controle de insetos. Revista de Ciências Ambientais, v. 6, n. 2, p. 92-112, 2013. Disponível em: <www.revistas.unilasalle.edu.br/index.php/Rbca/article/download/870/766>. Acesso em: 15 ago. 2015.

MEDICE, R.; ALVES, E.; ASSIS, R. T.; MAGNO JÚNIOR, R. G.; LOPES, E. A. G. L. Óleos essenciais no controle da ferrugem asiática da soja Phakopsora pachyrhizi Syd. \& P. Syd. Ciência e Agrotecnologia, v. 31, n. 1, p. 8390, 2007. Disponível em: <http://www.scielo.br/scielo. php?script=sci_arttext\&pid=S1413-70542007000100013 >. Acesso em: 24 set. 2015.

MORAIS, S. M.; CATUNDA JUNIOR, F. E. A.; SILVA, A. R. A.; MARTINS NETO, J. S.; RONDINA, D.; CARDOSO, J. H. L. Atividade antioxidante de óleos essenciais de espécies de Croton do Nordeste do Brasil. Química Nova, v. 29, n. 5, p. 907, 2006. Disponível em: <http://www.scielo.br/scielo. php?script=sci_arttext\&pid=S0100-40422006000500004 >. Acesso em: 10 out. 2015.

NAGPAL, N.; SHAH, G.; ARORA, N. M.; SHRI, R.; ARYA, Y. Phytochemical and pharmacological aspects of Eucalyptus genus. International Journal of Pharmaceutical Sciences and Research (IJPSR), v. 1 , n. 12, p. 28-36, 2010.

NÓBREGA, R. A.; MOTTA, S. C.; LEITE, J. R. Óleos essenciais com propriedades anticonvulsivantes. Boletín Latinoamericano y del Caribe de Plantas Medicinales y Aromáticas, v. 2, n. 1, p. 36, 2003. Disponível em: <http://www.redalyc.org/pdf/856/85620103.pdf>. Acesso em: 15 out. 2015.

OYEDEJI, O. O.; OLADIPUPO, A. L.; FRANCIS, O. S.; ADEBOLA. O. O. Chemical composition and antibacterial activity of the essential oils of Callistemon citrinus and Callistemon viminalis from South Africa. Molecules, v. 14, n. 6, p. 1990-1998, 2009. Disponível em: <https://www.researchgate.net/profile/Francis_Shode2/publication/26279342_Chemical_Composition_and_Antibacterial_Activity_of_the_Essential_Oils_of/links/0912f508e73164c113000000/Chemical-Composition-and-Antibacterial-Activity-of-the-Essential-Oils-of.pdf>. Acesso em: 17 set. 2015.

PEREIRA, F. O. Atividade antifúngica do óleo essencial de Cymbopogon winterianus Jowitt ex Bor sobre dermatófitos do gênero Trichophyton. 2009. 119 p. Dissertação (Mestrado em Farmacologia) - Universidade Federal da Paraíba (UFPB), João Pessoa, 2009.

PEREIRA, R. S.; SUMITAA, T. C.; FURLANB, M. R.; JORGEC, A. O.; UENOET, M. Atividade antibacteriana de óleos essenciais em cepas isoladas de infecção urinária. Revista de Saúde Pública, v. 38, n. 2, p. 326-328, 2004. Disponível em: <http://www.scielo.br/pdf/rsp/v38n2/19796.pdf>. Acesso em: 16 set. 2015 .

PIATTI, A.; SCHNEIDER, C. F.; NOZAKI, M. H. Efeito in vitro do óleo essencial de Eucalyptus globulus sobre o crescimento e desenvolvimento de Penicillium sp. Semina: Ciências Agrárias, v. 32, n. 3, p. 1033-1040, 2011. Disponível em: <http://www.redalyc.org/html/4457/445744109020/>. Acesso em: 28 out. 2015.

POZZA, E. A.; SOUZA, P. E. de; CASTRO, H. A.; POZZA, A. A. Freqüência da ocorrência de doenças da parte aérea de plantas na região de Lavras/MG. Ciência e Agrotecnologia, Lavras, v. 23, n. 4, p. 1001-1005, 1999. Disponível em: <http://www.editora.ufla.br/index.php/component/phocadownload/category/34-volume-23-numero-4?download=492:vol23numero4 > . Acesso em: 03 out. 2015. 
SILVA, D. M. H.; BASTOS, C. N. Atividade antifúngica de óleos essenciais de espécies de Piper sobre Crinipellis perniciosa, Phytophthora palmivora e Phytophthora capsici. Fitopatologia Brasileira, v. 32, n. 2, p. 143-145, 2007. Disponível em: <http://www.scielo.br/scielo.php?script=sci_arttext\&pid $=$ S0100-41582007000200008 > . Acesso em: 24 out. 2015.

SILVA, R. R.; COELHO, G. D. Fungos: principais grupos e aplicações biotecnológicas. Curso de capacitação de monitores e educadores. Programa de Pós-Graduação em Biodiversidade Vegetal e Meio Ambiente. São Paulo, 2006. 20 p. Disponível em: <http://www.biodiversidade.pgibt.ibot. sp.gov.br/Web/pdf/Fungos_Ricardo_Silva_e_Glauciane_Coelho.pdf>. Acesso em: 24 out. 2015.

SOARES, A. G. Desperdício de Alimentos no Brasil. Um desafio político e social a ser vencido. Embrapa Agroindústria de Alimentos, 2014. Disponível em: <http://atividaderural.com.br/artigos/ 508fc56454d19.pdf>. Acesso em: 25 out. 2015.

SOUZA, D. C.; SALVAIA, A.; LOURENÇO S. A.; AMORIM, L. Eficiência de fungicidas e óleos essenciais na inibição in vitro de Monilinia fructicola. Biológico, São Paulo, v. 68, p. 599-603, 2006. Disponível em: <http://www.biologico.sp.gov.br/docs/bio/suplementos/v68_supl/p599-603.pdf>. Acesso em: 14 set. 2015.

Histórico editorial:

Submetido em: 11/04/2016

Aceito em: 05/07/2016

Como citar:

ABNT

COUTO, D. A.; DIAS, F. S.; SÁBER, M. L. Antimicrobial activity of essential oils on pathogenic fungi. Revista Agrogeoambiental, Pouso Alegre, v. 9, n. 3, p. 37-46, jul./set.

Doi: http://dx.doi.org/10.18406/2316-1817v9n32017979

APA

COUTO, D. A., DIAS, F. S. \& SÁBER, M. L. (2017). Antimicrobial activity of essential oils on pathogenic fungi. Revista Agrogeoambiental, Pouso Alegre, 9 (3), 37-46.

Doi: http://dx.doi.org/10.18406/2316-1817v9n32017979

ISO

COUTO, D. A.; DIAS, F. S. e SÁBER, M. L. Antimicrobial activity of essential oils on pathogenic fungi. Revista Agrogeoambiental, 2017, vol. 9, n. 3, pp. 37-46. Eissn 2316-1817.

Doi: http://dx.doi.org/10.18406/2316-1817v9n32017979

\section{VANCOUVER}

Couto DA, Dias FS, Sáber ML. Antimicrobial activity of essential oils on pathogenic fungi. Rev agrogeoambiental. 2017 jul/set; 9(3): 37-46.

Doi: http://dx.doi.org/10.18406/2316-1817v9n32017979 